\title{
EFEK PEMBERIAN MADU TRIGONA TERHADAP KADAR ALBUMIN TIKUS PUTIH YANG DIINDUKSI ATORVASTATIN
}

The Effects of Trigona Honey provision on Atorvastatin-induced White Rat Albumin

\author{
Mirnawati Salampe $^{1 *}$, Sukamto S Mamada $^{2}$ \\ ${ }^{1}$ Sekolah Tinggi Ilmu Farmasi Makassar, Makassar, Indonesia \\ ${ }^{2}$ Fakultas Farmasi Universitas Hasanuddin, Makassar, Indonesia \\ *Koresponden Email: mirnasalampe@ymail.com
}

DOI: https://doi.org/10.32382/mf.v16il.1376

\begin{abstract}
Honey has antioxidant activity that prevents oxidative stress due to high doses of atorvastatin. This study determines the effect of trigona honey provision on albumin levels of white rats given high doses of atorvastatin. Twenty-four white rats (Rattus norvegicus) were divided into 6 groups $(n=4)$, and each was subjected to different treatment for 5 weeks. One group was given two doses of atorvastatin $20 \mathrm{mg} / \mathrm{kg}$ for 3 weeks, followed by $40 \mathrm{mg} / \mathrm{kg}$ for 2 weeks. Group 1, normal control, received $0.5 \% \mathrm{NaCMC}$, group 2 negative control received atorvastatin, and group 3- honey control received $4.5 \mathrm{ml} / \mathrm{kgBB}$ of honey. Groups 4, 5, and 6 each were given Trigona honey at a doses of $1.5 \mathrm{ml} / \mathrm{kgBB}, 3 \mathrm{ml} / \mathrm{kgBB}$, and $4.5 \mathrm{ml} /$ $\mathrm{kgBB}$, each with atorvastatin. The results showed that the highest albumin level was in the normal control of $2.83 \mathrm{mg} / \mathrm{dl}$, while the lowest was in the negative control of $2.38 \mathrm{mg} / \mathrm{dl}$. Furthermore, groups $3,4,5$, and 6 had albumin levels of 2.55, 2.53, 2.63, and $2.53 \mathrm{mg} / \mathrm{dl}$, respectively. Statistical analysis showed that there were significant differences $(\mathrm{p}<0.05)$ between negative and normal controls. However, there was no significant difference ( $p>0.05$ ) between negative controls and three groups of animals given trigona honey with atorvastatin induction. Therefore, the trigona honey did not have a preventive effect on changes in albumin levels in atorvastatin-induced rats.
\end{abstract}

Keywords: atorvastatin, Trigona honey, albumin

\begin{abstract}
ABSTRAK
Madu memiliki aktivitas antioksidan yang mampu mencegah stress oksidatif yang diakibatkan oleh penggunaan atorvastatin dosis tinggi. Penelitian ini bertujuan untuk mengetahui pengaruh pemberian madu trigona terhadap kadar albumin tikus putih yang diberi atorvastatin dosis tinggi. Dua puluh empat ekor tikus putih (Rattus norvegicus) dibagi ke dalam 6 kelompok $(n=4)$. Masing-masing kelompok mendapatkan perlakuan yang berbeda selama 5 minggu dimana kelompok yang diberikan atorvastatin mendapatkan dua dosis atorvastatin yaitu $20 \mathrm{mg} / \mathrm{kg}$ selama 3 minggu dan dilanjutkan $40 \mathrm{mg} / \mathrm{kg}$ selama 2 minggu. Kelompok 1 (kontrol normal) mendapatkan NaCMC $0.5 \%$, kelompok 2 (kontrol negatif) mendapatkan atorvastatin, dan kelompok 3 (kontrol madu) mendapatkan madu 4,5 ml $/ \mathrm{kgBB}$. Adapun kelompok 4, 5, dan 6 masing-masing diberikan madu Trigona dengan dosis 1,5 ml/kgBB dan atorvastatin, $3 \mathrm{ml} / \mathrm{kgBB}$ dan atorvastatin, dan $4,5 \mathrm{ml} / \mathrm{kgBB}$ dan atorvastatin. Hasil penelitian menunjukkan bahwa kadar albumin tertinggi terdapat pada kontrol normal $2.83 \mathrm{mg} / \mathrm{dl}$ dan kadar albumin terendah pada kontrol negatif $2.38 \mathrm{mg} / \mathrm{dl}$, sedangkan kelompok 3, 4, 5 dan 6 memiliki kadar albumin $2.55 ; 2.53 ; 2.63 ; 2.53$ $\mathrm{mg} / \mathrm{dl}$ berturut-turut. Analisis statistik menunjukkan bahwa terdapat perbedaan yang bermakna $(\mathrm{p}<0.05)$ antara kontrol negatif dengan kontrol normal dan tidak ada perbedaan yang bermakna $(p>0.05)$ antara kontrol negatif dengan tiga kelompok hewan yang diberikan madu trigona disertai induksi atorvastatin. Penelitian ini menyimpulkan bahwa pemberian madu trigona belum memberikan efek preventif atas perubahan kadar albumin pada tikus yang diinduksi atorvastatin.
\end{abstract}

Kata Kunci: atorvastatin, madu Trigona, albumin

\section{PENDAHULUAN}

Atorvastatin

merupakan

antihiperlipidemia golongan statin yang secara kompetitif menghambat sisi aktif enzim 3hydroxy-3-methylglutaryl-coenzyme A (HMG$C o A)$ reductase. Penghambatan enzim tersebut mencegah konversi HMG-CoA menjadi asam mevalonate, sehingga terjadi penurunan produksi kolesterol di hati. Statin juga diketahui meningkatkan jumlah reseptor LDL (LDL-R) di permukaan hepatosit. Pleiotropic effect yang ditunjukkan oleh statin membuat penggunaan obat ini relative populer dibandingkan obat-obat lain yang sejenis. Namun, penggunaan statin, termasuk atorvastatin, yang tidak sesuai dapat memunculkan efek samping yang merugikan. 
Salah satu di antaranya adalah hepatotoksisitas (Stancu \& Sima, 2001; Björnsson, 2017).

Mekanisme hepatotoksisitas dari statin dikaitkan dengan penurunan komposisi lipid membran hepatosit. Kondisi ini menyebabkan peningkatan permeabilitas membran sel, menyebabkan kebocoran enzim intraseluler, dan dapat menginduksi stress oksidatif (Karahalil et al., 2017). Stress oksidatif ditandai dengan peningkatan kadar malondialdehid (MDA) dan penurunan aktivitas antioksidan enzimatik. Menurut studi, tikus yang diberikan atorvastatin menunjukkan peningkatan kadar MDA dan penurunan aktivitas antioksidan enzimatik superoxide dismutase (SOD) (Salampe et al., 2018).

Penggunaan atorvastatin dosis tinggi dilaporkan menyebabkan elevasi amino transferase, bilirubin, dan penurunan serta gangguan fungsi albumin (Ward et al., 2019). Gangguan pada hepatosit menghasilkan perubahan modifikasi pascatranslasi albumin, sehingga fungsi albumin terganggu yang dapat berakibat pada kerusakan pengaturan tekanan onkotik plasma (Carvalho \& Machado, 2018). Abnormalitas biokimia hati merupakan penanda hepatotoksisitas pada penggunaan statin. Penelitian menunjukkan bahwa pasien yang menggunakan atorvastatin 40-80 mg selama enam bulan atau lebih mengalami kerusakan hati dan hepatitis autoimun (Clarke et al., 2016).

Upaya yang dapat dilakukan dalam pencegahan efek samping hepatotoksisitas statin yang dikaitkan dengan stress oksidatif yaitu melalui penggunaan antioksidan. Beberapa penelitian menunjukkan bahwa bahan alam yang mengandung senyawa flavonoid dan polifenol memiliki efek hepatoprotektif yang kuat (Gupta et al., 2004; Upadhyay et al., 2010).

Salah satu bahan alam yang mempunyai aktivitas antioksidan yang kuat yaitu madu trigona. Aktivitas antioksidan dari madu trigona dikaitkan dengan kandungan senyawa fenolik, dimana fenolik mempunyai kemampuan untuk mereduksi dan membentuk ikatan khelat dengan ion ferri yang mengkatalisis peroksidasi lipid (Krishnasree \& Ukkuru, 2015).

Madu trigona merupakan jenis madu yang dihasilkan oleh genus Trigona. Walaupun penggunaannya menjanjikan, tetapi penelitian terhadap jenis madu ini masih sangat kurang. Belum ada bukti ilmiah mengenai efek madu trigona dalam pencegahan efek hepatotoksisitas penggunaan atorvastatin.

Berdasarkan hal tersebut, penelitian ini dilakukan untuk mengetahui pengaruh pemberian madu trigona terhadap kadar albumin tikus putih yang diberi atorvastatin dosis tinggi.

\section{METODE}

\section{Desain, tempat dan waktu}

Desain penelitian merupakan posttest control group design yang dilakukan di laboratorium Biofarmasi Fakultas Farmasi Unhas dan Laboratorium Patologi Klinik RS Universitas Hasanuddin.

\section{Alat dan Bahan}

Alat

Spoit (Terumo®), kanula, vacutainer merah (Vaculab®), tabung eppendorf, sentrifuge Human () , labu ukur (Pyrex®), corong kaca (Yenaco®), gelas ukur (Pyrex®), timbangan analitik, sendok tanduk besi, mikropipet (Human®), dan Abx Pentra 400 (Horiba®)

\section{Bahan}

Tablet Atorvastatin, madu trigona yang diperoleh dari peternak madu trigona di Hutan Bengo-Bengo Unhas, Tween 80 5\%, NaCMC $0.5 \%$, etanol $70 \%$, kit pengukuran (albumin), pakan pellet $\mathrm{AD}$ II, aquades.

\section{Penyiapan dan Perlakuan Hewan Uji}

Hewan yang digunakan pada penelitian ini adalah hewan tikus putih jantan galur albino (Rattus norvegicus) dengan bobot $180-250 \mathrm{~g}$ sebanyak 24 ekor dan memiliki kondisi sehat yang dapat diamati secara fisik dan perilaku. Hewan diperoleh dari tempat pemeliharaan tikus Mestro FC, Surabaya, Indonesia. Penelitian ini telah mendapatkan izin etik dari Komite Etik Penelitian Kesehatan Universitas Hasanuddin. Aklimatisasi dilakukan terhadap hewan uji selama tujuh hari dengan pemberian pakan pellet $\mathrm{AD}$ II serta penggantian sekam rutin 2 kali dalam seminggu. Secara acak, hewan coba dibagi ke dalam 6 kelompok dimana setiap kelompok terdiri atas 4 ekor tikus putih

- Kelompok 1 (kontrol normal) mendapatkan $\mathrm{NaCMC} \mathrm{0,5 \%}$

- Kelompok 2 (kontrol negatif) mendapatkan atorvastatin $20 \mathrm{mg} / \mathrm{kg}$ selama 3 minggu dan dilanjutkan $40 \mathrm{mg} / \mathrm{kg}$ selama 2 minggu

- Kelompok 3 (kontrol madu) mendapatkan madu $4,5 \mathrm{ml} / \mathrm{kgBB}$

- Kelompok 4 mendapatkan madu 1,5 $\mathrm{ml} / \mathrm{kgBB}$ + atorvastatin $20 \mathrm{mg} / \mathrm{kg}$ selama 3 minggu dan dilanjutkan $40 \mathrm{mg} / \mathrm{kg}$ selama 2 minggu

- Kelompok 5 mendapatkan madu 3 $\mathrm{ml} / \mathrm{kgBB}$ + atorvastatin $20 \mathrm{mg} / \mathrm{kg}$ selama 3 
minggu dan dilanjutkan $40 \mathrm{mg} / \mathrm{kg}$ selama 2 minggu

- Kelompok 6 mendapatkan madu 4,5 $\mathrm{ml} / \mathrm{kgBB}$ + atorvastatin $20 \mathrm{mg} / \mathrm{kg}$ selama 3 minggu dan dilanjutkan $40 \mathrm{mg} / \mathrm{kg}$ selama 2 minggu

Pemberian NaCMC, madu, dan atorvastatin pada semua kelompok uji dilakukan setiap hari selama 5 minggu (madu diberikan terlebih dahulu dengan rentang waktu 2 jam sebelum pemberian atorvastatin). Atorvastatin diberikan dengan dosis $20 \mathrm{mg} / \mathrm{kg}$ pada minggu pertama sampai ke-3, selanjutnya dosis ditingkatkan menjadi $40 \mathrm{mg} / \mathrm{kg}$ pada minggu ke-4 dan ke-5.

\section{Pengukuran kadar Albumin}

Hewan uji diperlakukan sesuai dengan kelompok masing-masing secara per oral selama 5 minggu berturut-turut. Setelah perlakuan, pengambilan darah dilakukan untuk pengukuran kadar albumin. Darah yang telah diambil kemudian disentrifugasi selama 15 menit dengan kecepatan 3000 rpm lalu diambil bagian serumnya. Serum dianalisis dengan menggunakan ABX Pentra 400 (Horiba®).

\section{Analisis Data}

Data kadar Albumin yang terdistribusi normal dan homogen selanjutnya diolah secara statistik menggunakan ANOVA lalu dilanjutkan uji Bonferroni post hoc test sebagai proses untuk menarik kesimpulan. Setelah dilakukan analisis data, dilakukan pembahasan berdasarkan hasil yang diperoleh dari olah statistik. Dilakukan penarikan kesimpulan berdasarkan hasil yang telah dibahas.

\section{HASIL}

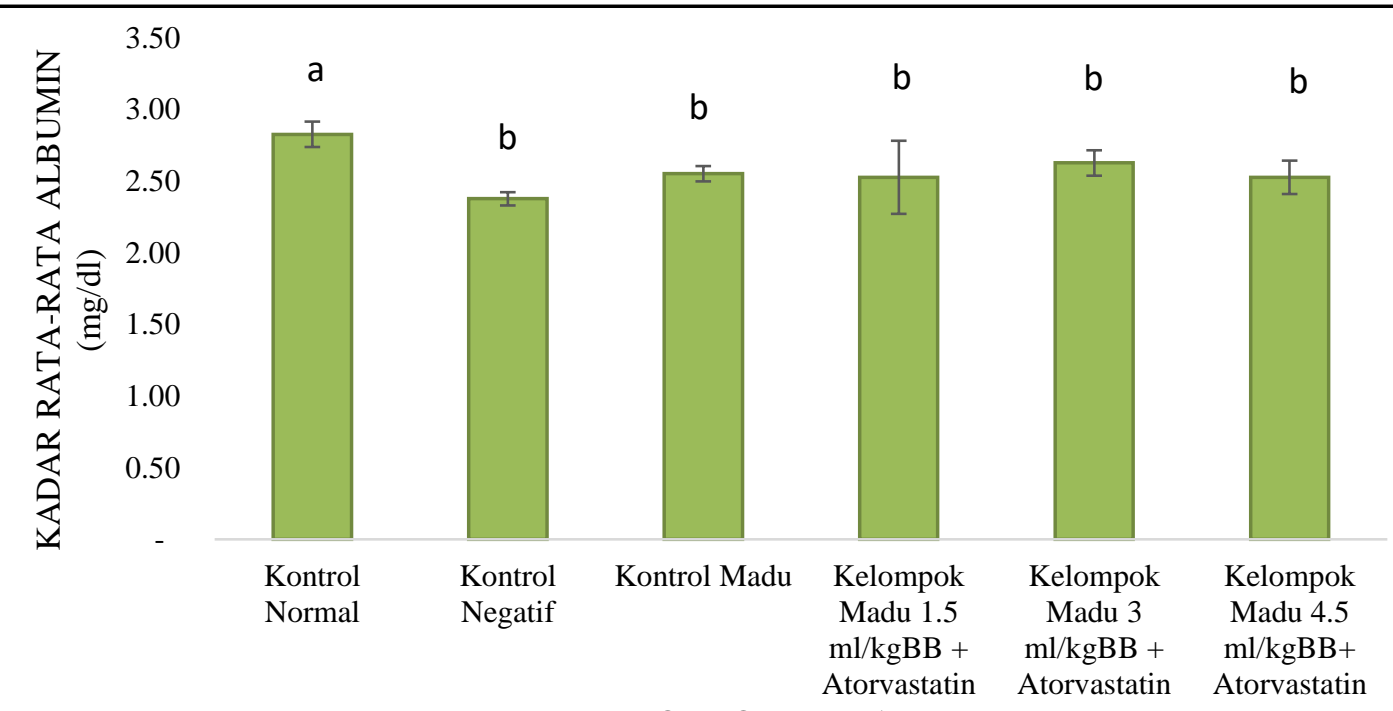

KELOMPOK HEWAN UJI

Gambar 1. Kadar albumin rata-rata kelompok hewan uji setelah perlakuan. Kelompok 1 (kontrol normal) diberikan NaCMC 0,5\%. Kelompok 2 (kontrol negatif) diberikan atorvastatin $20 \mathrm{mg} / \mathrm{kg}$ selama $3 \mathrm{minggu}$ dan $40 \mathrm{mg} / \mathrm{kg}$ selama 2 minggu. Kelompok 3 diberikan madu $4,5 \mathrm{ml} / \mathrm{kgBB}$. Kelompok 4 diberikan madu $1,5 \mathrm{ml} / \mathrm{kgBB}$ + atorvastatin $20 \mathrm{mg} / \mathrm{kg}$ selama $3 \mathrm{minggu}$ dan $40 \mathrm{mg} / \mathrm{kg}$ selama $2 \mathrm{minggu}$. Kelompok 5 diberikan madu $3 \mathrm{ml} / \mathrm{kgBB}$ + atorvastatin $20 \mathrm{mg} / \mathrm{kg}$ selama 3 minggu dan $40 \mathrm{mg} / \mathrm{kg}$ selama $2 \mathrm{minggu}$. Kelompok 6 diberikan madu 4,5 ml/kgBB + atorvastatin $20 \mathrm{mg} / \mathrm{kg}$ selama $3 \mathrm{minggu}$ dan $40 \mathrm{mg} / \mathrm{kg}$ selama 2 minggu

Superskrip yang berbeda menunjukkan perbedaan yang signifikan $(\mathrm{p}<0,05)$

Setelah dilakukan perlakuan selama lima minggu, diperoleh kadar albumin pada semua kelompok hewan uji seperti yang terdapat pada Gambar 1. Hasil penelitian menunjukkan bahwa kadar albumin pada hewan uji kontrol negatif lebih rendah dibandingkan dengan kelompok yang lainnya. Kontrol negatif merupakan hewan uji yang diinduksi atorvastatin $20 \mathrm{mg} / \mathrm{kg}$ selama 3 minggu dan dilanjut dengan dosis $40 \mathrm{mg} / \mathrm{kg}$ selama 2 
minggu. Kadar albumin tertinggi terdapat pada kelompok kontrol normal (diberikan NaCMC selama 5 minggu) dan kelompok kontrol madu (diberikan madu $4.5 \mathrm{ml} / \mathrm{kgBB}$ tanpa induksi atorvastatin).

Kadar albumin pada gambar 1 diolah secara statistik menggunakan metode ANOVA yang dilanjut dengan uji post hoc Bonferroni. Hasil statistik menunjukkan terdapat perbedaan yang bermakna $(\mathrm{p}<0.05)$ antara kelompok kontrol negatif dengan kelompok kontrol normal. Hal ini mengindikasikan bahwa pemberian simvastatin menyebabkan kadar albumin lebih rendah pada hewan uji yang diinduksi atovarstatin. Sedangkan antara kontrol negatif dengan kelompok hewan yang diberikan madu disertai dengan induksi atorvastatin tidak menunjukkan perbedaan bermakna $(\mathrm{p}>0.05)$. Tiga kelompok lainnya yang diberikan madu dosis berbeda dan diinduksi atorvastatin juga menunjukkan perbedaan yang tidak bermakna.

\section{PEMBAHASAN}

Statin merupakan golongan antihiperlipidemia yang menghambatan enzin HMG-CoA reduktase sehingga menurunkan produksi kolestrol endogen melalui jalur asam mevalonat. Salah satu contoh golongan statin yang bersifat lipofilik yaitu atorvastatin. Statin lipofilik sangat mudah melewati membrane sel sehingga mempengaruhi hepatik dan extrahepatik HMG-CoA reduktase (Stancu \& Sima, 2001; Baer \& Wortmann, 2007).

Selain menurunkan produksi kolestrol, statin juga menyebabkan deplesi sejumlah metabolit isoprenoid sebagai akibat dari inhibisi enzim HMG-CoA reduktase. Deplesi isoprenoid tersebut, menjelaskan efek dari statin yang tidak terkait dengan penurunan kolesterol. Meskipun umumnya statin ditoleransi dengan baik, tetapi statin dapat menimbulkan berbagai macam efek samping (Baer \& Wortmann, 2007). Efek samping yang dapat terjadi pada penggunaan statin yaitu hepatotoksisitas (Björnsson, 2017). Salah satu parameter penilaian fungsi hati pada kondisi hepatotoksisitas yaitu kadar albumin.

Kadar albumin yang rendah pada kontrol negatif merupakan salah satu indikasi gangguan fungsi hati. Dilaporkan bahwa atorvastatin dosis tinggi dikaitkan dengan resiko gangguan fungsi hati yang serius (Clarke et al., 2016b). Mekanisme statin menginduksi kerusakan hati tidak sepenuhnya diketahui. Disfungsi mitokondria merupakan salah satu proses mekanisme toksisitas dari statin. Dilaporkan bahwa gangguan mitokondria secara in-vitro tergantung pada dosis dan waktu pajanan. Statin menyebabkan terjadinya gangguan depolarisasi membrane mitokondria, pelepasan $\mathrm{Ca}^{2+}$, gangguan rantai respiratori kompleks I dan III, serta menyebabkan apoptosis sel. Atorvastatin adalah statin yang bersifat lipofilik sehingga secara luas mengalami metabolisme di hati oleh enzim CYP. Proses metabolisme statin oleh CYP menyebabkan peningkatan produksi ROS di hepatosit. Hal ini menyebabkan penurunan potensial membrane mitokondria (Karahalil et al., 2017; Thotakura, Singh, Khera, Chauhan, \& Devasia, 2018).

Studi lain melaporkan bahwa penggunaan atorvastatin $10 \mathrm{mg} / \mathrm{kg} /$ hari selama dua minggu pada tikus meningkatkan akumulasi $\mathrm{H}_{2} \mathrm{O}_{2}$, kadar mRNA dan immunostaining dari $\mathrm{Bax} / \mathrm{Bcl}-2$ ratio. Atorvastatin juga menurunkan rasio GSH/GSSG serta mengaktivasi jalur signal apoptosis mitokondria. Co-treatment dengan antioxidan quercetin $25 \mathrm{mg} / \mathrm{kg} / \mathrm{hari}$ dapat memperbaiki efek miopati tersebut (Bouitbir et al., 2012).

Hepatotoksisitas statin tergantung waktu (timedependent effect) dan dosis (dosedependent effect). Beberapa penelitian melaporkan bahwa pemberian statin justru memiliki efek hepatoprotektif. Salah satu penelitian melaporkan bahwa pemberian simvastatin dosis $40 \mathrm{mg} / \mathrm{kgBB}$ selama 15 hari tidak meningkatkan kadar SGPT dan SGOT. Selanjutnya suplementasi madu trigona yang memiliki potensi sebagai antioksidan semakin menurunkan kadar SGPT secara nyata pada tikus (Mamada et al., 2018).

Terkait dengan mekanisme atorvastatin menyebabkan efek toksisitas karena terjadi stress oksidatif, maka upaya yang dapat dilakukan untuk mencegah hal tersebut adalah mencari sumber antioksidan yang dapat menghentikan proses oksidatif. Salah satu sumber antioksidan secara alami yaitu madu. Madu memiliki kandungan senyawa polifenol, flavonoid, dan flavonol yang memiliki aktivitas antioksidan (Krishnasree \& Ukkuru, 2015). Fenol sangat efektif sebagai penangkal radikal peroksil karena struktur molekulnya meliputi cincin aromatik dengan gugus hidroksil yang mengandung mobile hydrogen. Senyawa fenolik mempunyai kemampuan untuk mereduksi dan membentuk ikatan khelat dengan ion ferri yang mengkatalisis peroksidasi lipid (Uttara et al., 2009). Beberapa studi menunjukkan bahwa madu dari spesies trigona memiliki aktifitas antioksidan yang tinggi (Rao et al., 2016).

Walaupun hasil penelitian kadar albumin (gambar 1) pada kelompok hewan yang diberikan madu dan diinduski atorvastatin tidak berbeda secara nyata dengan kelompok kontrol 
negatif, akan tetapi kadar albumin pada hewan uji yang diberikan madu lebih tinggi dibandingkan dengan hewan uji yang hanya diinduksi atorvastatin. Tiga kelompok hewan uji yang diberikan madu $1.5 ; 3 ; 4.5 \mathrm{ml} / \mathrm{kgBB}$ berturut turut juga tidak menunjukkan perbedaan yang bermakna. Hal tersebut menunjukkan bahwa tidak ada perbedaan efek dari tiga variasi dosis madu yang diberikan terhadap perubahan kadar albumin.

Albumin merupakan protein yang disintesis di hati sehingga pemeriksaan kadar albumin merupakan salah satu penanda gangguan fungsi hati. Penelitian lain melaporkan bahwa pemberian madu memberikan efek proteksi dengan memperbaiki parameter fungsi hati salah satunya meningkatkan kadar albumin pada tikus yang diinduksi melamin (El Rabey et al., 2013). Penelitian terkait efek madu terhadap kadar albumin pada hewan uji yang diinduksi atorvastatin belum pernah dilaporkan sehingga perbandingan hasil penelitian ini belum bisa dilakukan.

Hasil penelitian tersebut diatas menunjukkan adanya potensi madu trigona untuk digunakan sebagai suplementasi pada penggunaan statin, walaupun secara statistik tidak ada perbedaan yang bermakna pada hewan uji kontrol negatif dengan hewan uji yang diberikan madu trigona. Oleh karena itu, untuk memastikan efek pemberian madu trigona pada tikus yang diinduksi atorvastatin diperlukan pemeriksaan parameter fungsi hati selain albumin. Parameter fungsi hati yang dapat dinilai pada penggunaan atorvastatin yaitu alanine aminotransferase, aspartate aminotransferase, alkaline phosphatase, total bilirubi (Carrascosa et al., 2015).

Untuk menghindari kemungkinan interaksi yang terjadi, perlu dilakukan interval waktu penggunaan madu dan statin sebelum ada hasil penelitian yang membuktikan efek interaksi yang terjadi.

\section{KESIMPULAN}

Berdasarkan hasil penelitian dan pembahasan yang dilakukan, dapat ditarik kesimpulan pemberian madu trigona belum memberikan efek preventif atas perubahan kadar albumin pada tikus yang diinduksi atorvastatin.

\section{SARAN}

Perlu dilakukan pemeriksaan parameter yang lain untuk menilai efek dari pemberian madu trigona pada tikus yang diinduksi atorvastatin

\section{UCAPAN TERIMA KASIH}

Terima kasih kepada pihak LPDP_BUDI-DN atas bantuan dana yang telah diberikan sehingga pelaksanaan penelitian ini berjalan dengan lancar.

\section{DAFTAR PUSTAKA}

Baer, A. N., \& Wortmann, R. L. (2007). Myotoxicity associated with lipidlowering drugs. Current Opinion in Rheumatology, 19(1), 67-73. https://doi.org/10.1097/BOR.0b013e3280 $10 \mathrm{c} 559$

Björnsson, E. S. (2017). Hepatotoxicity of statins and other lipid- - lowering agents. Liver International, 37(July 2016), 173178. https://doi.org/10.1111/liv.13308

Bouitbir, J., Charles, A. L., Echaniz-Laguna, A., Kindo, M., Daussin, F., Auwerx, J., Piquard, F., Geny, B., \& Zoll, J. (2012). Opposite effects of statins on mitochondria of cardiac and skeletal muscles: A "mitohormesis" mechanism involving reactive oxygen species and PGC-1. European Heart Journal, 33(11), 1397-1407.

https://doi.org/10.1093/eurheartj/ehr224

Carrascosa, M. F., Salcines-Caviedes, J. R., Lucena, M. I., \& Andrade, R. J. (2015). Acute liver failure following atorvastatin dose escalation: Is there a threshold dose for idiosyncratic hepatotoxicity? Journal of Hepatology, 62(3), 751-752. https://doi.org/10.1016/j.jhep.2014.11.019

Carvalho, J. R., \& Machado, M. V. (2018). New Insights About Albumin and Liver Disease. Journal of the Mexican Association of Hepatology, 17(4), 547560. https://doi.org/10.5604/01.3001.0012.091 6

Clarke, A. T., Johnson, P. C. D., Hall, G. C., Ford, I., \& Mills, P. R. (2016a). High dose atorvastatin associated with increased risk of significant hepatotoxicity in comparison to simvastatin in UK GPRD cohort. PLoS ONE, 11(3), 1-13. https://doi.org/10.1371/journal.pone.0151 587

Clarke, A. T., Johnson, P. C. D., Hall, G. C., Ford, I., \& Mills, P. R. (2016b). High Dose Atorvastatin Associated with Increased Risk of Significant Hepatotoxicity in Comparison to 
Simvastatin in UK GPRD Cohort. Plos ONE, 11(3), 1-13. https://doi.org/10.1371/journal.pone.0151 587

El Rabey, H. A., Al-Seeni, M. N., \& AlSolamy, S. M. (2013). Bees' honey protects the liver of male rats against melamine toxicity. BioMed Research International, 2013, 14-16. https://doi.org/10.1155/2013/786051

Gupta, Y. K., Sharma, M., Chaudhary, G., \& Katiyar, C. K. (2004). Hepatoprotective effect of New Livfit@, a polyherbal formulation, is mediated through its free radical scavenging activity. Phytotherapy Research, 18(5), 362-364. https://doi.org/10.1002/ptr.1272

Karahalil, B., Hare, E., Koç, G., Uslu, İ., Şentürk, K., \& Özkan, Y. (2017). Hepatotoxicity associated with statins. Arh Hig Rada Toksikol, 68, 254-260. https://doi.org/10.1515/aiht-2017-68-2994

Krishnasree, V., \& Ukkuru, P. M. (2015a). Phytochemical screening and antioxidant activity of diff erent bee honeys. Journal of Medicinal Herbs and Ethnomedicine, l(1), 38-44. https://doi.org/10.5455/jmhe.2015-07-013

Krishnasree, V., \& Ukkuru, P. M. (2015b). Phytochemical screening and antioxidant activity of different bee honeys. Journal of Medicinal Herbs and Ethnomedicine, l(1),

38. https://doi.org/10.5455/jmhe.2015-07-013

Mamada, S. S., Usmar, Aliyah, Rahayu, A. I., Hidayat, K., \& Salampe, M. (2018). Pengaruh Suplementasi Madu Trigona terhadap Parameter Fungsi Hati dan Ginjal Tikus Albino ( Rattus norvegicus ) yang Diberikan Simvastatin ( Effect of Trigona Honey Supplementation on Liver and Kidney Function in Simvastatin-. Galenica Journal of Pharmacy, 4(1), 3643.

https://doi.org/10.22487/j24428744.2017. v4.i1.9960
Rao, P. V., Krishnan, K. T., Salleh, N., \& Gan, S. H. (2016). Biological and therapeutic effects of honey produced by honey bees and stingless bees: A comparative review. Brazilian Journal of Pharmacognosy, 26(5), 657-664. https://doi.org/10.1016/j.bjp.2016.01.012

Salampe, M., Kabo, P., \& Djabir, Y. Y. (2018). pengaruh madu trigona terhadap stress oksidatif pada tikus putih ( rattus norvegicus ) yang diinduksi statin untuk mencegah miotoksisitas. Majalah Farmasi Dan Farmakologi, 22(2), 35-39.

Stancu, C., \& Sima, A. (2001). Statins: mechanism of action and effects. Journal of Cellular and Molecular Medicine, 5(4), 378-387. https://doi.org/10.1111/j.15824934.2001.tb00172.x

Thotakura, S., Singh, A., Khera, K., Chauhan, S., \& Devasia, T. (2018). AtorvastatinInduced Hepatotoxicity, Increased by Clopidogrel Stress on CYP450 Enzyme: Understanding the Mechanism through a Case. Journal of Applied Pharmaceutical Science, $\quad 8(04), \quad 168-170$. https://doi.org/10.7324/JAPS.2018.8424

Upadhyay, G., Tiwari, M. N., Prakash, O., Jyoti, A., Shanker, R., \& Singh, M. P. (2010). Involvement of multiple molecular events in pyrogallol-induced hepatotoxicity and silymarin-mediated protection: Evidence from gene expression profiles. Food and Chemical Toxicology, 48(6), 1660-1670. https://doi.org/10.1016/j.fct.2010.03.041

Uttara, B., Singh, A. V, Zamboni, P., \& Mahajan, R. T. (2009). Oxidative Stress and Neurodegenerative Diseases: A Review of Upstream and Downstream Antioxidant Therapeutic Options. Current Neuropharmacology, 7(1), 65-74.

Ward, N. C., Watts, G. F., \& Eckel, R. H. (2019). Mechanistic Insights and Clinical Implications. Circulation Research, 124, 328-350.

https://doi.org/10.1161/CIRCRESAHA.11 8.312782 